NOTICE: This is the authors' version of a work that was accepted for publication in World Development. Changes resulting from the publishing process, such as peer review, editing, corrections, structural formatting, and other quality control mechanisms may not be reflected in this document. Changes may have been made to this work since it was submitted for publication. A definitive version was subsequently published in World Development, [40, 11, (2012)] http://dx.doi.org/10.1016/j.worlddev.2012.06.010.

\title{
Effects of Fair Trade certification on social capital: The case of Rwandan coffee producers
}

\author{
Sara D. Elder ${ }^{1}$, Hisham Zerriffi ${ }^{2}$, and Philippe Le Billon ${ }^{2}$ \\ ${ }^{1}$ Institute for Resources, Environment, \& Sustainability, University of British Columbia \\ ${ }^{2}$ Liu Institute for Global Issues, University of British Columbia
}

\begin{abstract}
Fair Trade certification may have important social effects on small-scale producers but empirical evidence is limited. We conducted logistic regressions using data from a 2009 survey of Rwandan coffee farmers to estimate the link between Fair Trade and social capital—measured as farmer trust and participation—while controlling for various other factors that could influence social capital, particularly membership in a cooperative organization. The results show a negative association between Fair Trade and farmer trust in cooperative leadership and a positive association with a perceived higher level of participation of women. Social capital is linked most significantly to farmers' interaction with their neighbors.
\end{abstract}

Keywords: Fair Trade, cooperatives, social capital, coffee, Africa, Rwanda 


\section{Acknowledgements}

A Social Sciences and Humanities Research Council of Canada grant and the University of British Columbia Bridge Program provided funding to conduct the research for this article. We are grateful to the Rwandan farmers and organizations who shared their knowledge and experience, and for the dedication and hard work of our research assistants in Rwanda. We would also like to thank three anonymous reviewers for their helpful comments and suggestions. 


\section{INTRODUCTION}

Fair Trade certification is designed to ameliorate the social, as well as economic and environmental conditions of producers in the developing world through production and trade standards (Raynolds, Murray, \& Heller, 2007). Certified Fair Trade products have moved from niche to mainstream market channels and are now sold by leading retailers like Wal-Mart, Costco, and McDonald's (Kolk, 2011; Raynolds, 2009). Certified Fair Trade retail sales total US\$ 4.8 billion globally (FLO, 2010), averaging an annual growth rate of 30 per cent (Potts et al., 2010). Fairtrade International (FLO) certifies 20 different products, including bananas, tea, sugar, cocoa, honey, cotton, cut flowers, and coffee. There are approximately 1.2 million producers participating in over 800 Fair Trade certified producer organizations in Latin America, Africa, and Asia that sell certified products across North America and Europe (FLO, 2010). Given the rapid growth of Fair Trade certified products, it is important to examine Fair Trade's impact on these farmers and their families—an estimated five million people (FLO, 2010)—in order to understand the certification's effectiveness as a market-based tool for improving the well-being of populations.

Of the four main sustainable coffee standards (Fair Trade, Organic, Rainforest Alliance and Utz Certified), Fairtrade International is the oldest, and supporting smallholders has been its starting point, while for Rainforest Alliance and Organic this has been environmental protection, and for Utz market-based mainstreaming of sustainability (Kolk, 2012). Fair Trade certification has the potential to increase farmer well-being not only through its economic standards, for which it is best known, but also through its social standards (Raynolds et al., 2007). Unlike other certification standards, Fair Trade standards require buyers to pay a guaranteed minimum price and a social premium to producers, and recommend that buyers provide pre-financing and long- 
term contracts. Fair Trade also includes specific environmental protection standards designed to ensure safe and sustainable agricultural and environmental practices and to protect and enhance biodiversity. Lesser known, however, is that in order for farmers to obtain Fair Trade certification they must also meet specific social standards of production. Fair Trade focuses on small coffee producers who rely on family members for farm work and do not hire permanent workers. While other standards certify individual and groups of farmers as well as contract farmers, Fair Trade only certifies small coffee producers that belong to a cooperative producer organization, of which the majority of members must be small producers. The cooperative organization must be set up in a transparent way and not discriminate against any particular member or social group, such as women (FLO, 2011).

Research on the outcomes of Fair Trade certification for producers has focused on questions related to the economic impacts (see Bacon, 2005; Imhof \& Lee, 2007; Levi \& Linton, 2003; Lyon, 2007; Murray, Raynolds, \& Taylor, 2003; Sick, 2008). There has been less in-depth attention to the social impacts of Fair Trade's cooperative and non-discrimination standards despite growing evidence that "social networks and the reciprocities that arise from them" (known as social capital) can improve a number of areas of human welfare (Schuller, Baron, \& Field, 2000). Both theoretical arguments and empirical evidence have shown the positive effects of social capital in areas as diverse as health, markets, and government administration (Grootaert, Narayan, Jones, \& Woolcock, 2004; Putnam, 2001; Woolcock, 1998).

This article focuses on Fair Trade's impact on social capital in order to broaden understanding of the certification's effectiveness at ameliorating the lives of small producers. We analyzed data from a 2009 survey of 175 Rwandan coffee farmers and informant interviews using logit regressions to estimate the link between Fair Trade certification and social capital- 
measured as farmer trust and participation-while controlling for various other factors that could have an influence on social capital, particularly membership in a cooperative organization. In the next section, we provide background on social capital and Fair Trade certification. Section 3 introduces the study setting and Section 4 explains the methods. Section 5 provides descriptive statistics from the survey and reports the results of the empirical analysis. Section 6 discusses the findings and reflects on general lessons from this case.

\section{SOCIAL CAPITAL AND FAIR TRADE}

Social capital can be defined as "social networks, the reciprocities that arise from them and the value of these for achieving mutual goals" (Baron, Field, \& Schuller, 2000). It has both cognitive manifestations, such as trust in others and norms of reciprocity, and structural manifestations, such as participation in voluntary organizations (Grootaert \& Bastelaer, 2002). Social capital can be bonding or bridging; bonding social capital refers to connections to people that share a similar social identity, while bridging social capital involves connections across explicit or institutionalized power gradients in society to people in influential positions (Szreter \& Woolcock, 2004). Critics of the social capital concept point out that there is no consensus on whether it manifests at an individual or collective level (Portes, 2000), that it is easy to confuse the ability to secure resources through networks with the resources themselves, and that there is a tendency to understate the negative aspects of social capital (Mohan \& Mohan, 2002; Portes \& Landolt, 2000; Rubio, 1997). Despite its limitations as a construct, social capital has been linked to important social outcomes like decreased crime, child welfare, better health, more effective government administration, lower political corruption, reduced tax evasion, enhanced market

performance, and improved educational achievement (Putnam, 2001; Sampson, Raudenbush, \& 
Earls, 1997; Verba, Schlozman, \& Brady, 1995; Woolcock, 2001). Social capital has also been linked to improved farm system performance and efficiency, and cooperation among farmers of different ethnicities in Sri Lanka (Uphoff \& Wijayaratna, 2000).

There has been limited attention in the literature to the social impacts of Fair Trade, but there is some evidence that Fair Trade improves both cognitive and structural dimensions of social capital of producers. Pirotte, Pleyers, \& Poncelet (2006) and Moberg (2005) report that certified producers develop social networks and a sense of community through shared work and regular meetings of their Fair Trade cooperative. Others remark that farmer commitment to Fair Trade standards generally can promote broad producer participation in their cooperative and their community (Raynolds, Murray, \& Taylor, 2004). Taylor (2005) and Utting (2009) attribute producer empowerment and consequent increases in civic participation to Fair Trade, and Bassett (2010), Utting (2009), and Lyon, Bezaury, and Mutersbaugh (2010) report that Fair Trade encourages women in particular to participate in producer cooperatives.

While descriptive studies of perceived impacts of Fair Trade are widely available, studies that provide a rigorous evaluation of Fair Trade certification are lacking. There are few studies that use extensive field data to compare Fair Trade certified producers with otherwise similar non-certified producers, correcting for differences in household characteristics (Ruben, 2008). Those few empirical studies focus on prices and productivity rather than social capital (see Becchetti \& Costantino, 2008; Ruben, 2008).

No study to our knowledge compares Fair Trade certified farmers with otherwise similar non-certified cooperative farmers and non-cooperatively organized farmers in order to discern whether benefits to farmers result primarily from Fair Trade certification or cooperative organization. Most studies of Fair Trade implicitly assume certification is the cause of 
cooperative organization, but cooperatives can also exist in the absence of Fair Trade certification. These "non-certified" cooperatives can have social capital benefits for producers, for example by providing a platform for frequent interaction of members and a democratic structure for participation in economic activities (Majee \& Hoyt, 2010). Several studies that address the social effects of Fair Trade compare Fair Trade cooperative farmers to noncooperatively organized farmers (see Arnould, Plastina, \& Ball, 2009; Jaffee, 2007), but we are aware of only one that compares members of Fair Trade certified cooperatives with members of non-certified cooperatives (see Parrish, Luzadis, \& Bentley, 2005), and it did not distinguish the benefits of cooperative organization from the benefits of simply selling coffee. We hypothesize that cooperative organization is in fact responsible for many of the effects on social capital, and that increases in social capital will be seen in cooperatives regardless of whether or not the cooperative has Fair Trade certification. Table 1 summarizes current evidence and our hypotheses of the effects on producer social capital of Fair Trade certification and of noncertified cooperative organization, and compares this to a situation where producers sell to a private entrepreneur not a cooperative. 
Table 1: Effects on social capital of three types of coffee farmer organization

\begin{tabular}{|c|c|c|c|}
\hline $\begin{array}{c}\text { Social capital } \\
\text { indicator }\end{array}$ & $\begin{array}{c}\text { Fair Trade certified } \\
\text { cooperative }\end{array}$ & $\begin{array}{l}\text { Non-certified } \\
\text { cooperative }\end{array}$ & $\begin{array}{c}\text { Private coffee washing } \\
\text { station } \\
\end{array}$ \\
\hline Trust & $\begin{array}{l}\text { Democratic producer } \\
\text { organization standard } \\
\text { facilitates building of } \\
\text { social networks and trust } \\
\text { in community and } \\
\text { cooperative board } \\
\text { members (Moberg, } \\
\text { 2005; Pirotte et al., } \\
\text { 2006; Utting, 2009) }\end{array}$ & $\begin{array}{l}\text { Democratic producer } \\
\text { organization facilitates } \\
\text { building of social } \\
\text { networks and trust in } \\
\text { both community and } \\
\text { cooperative board } \\
\text { members (Milford, } \\
\text { 2004; Majee \& Hoyt, } \\
\text { 2010) }\end{array}$ & $\begin{array}{l}\text { Interaction between } \\
\text { producers at a central } \\
\text { processing location } \\
\text { builds social networks; } \\
\text { may improve trust } \\
\text { among community } \\
\text { members but not trust in } \\
\text { private management } \\
\text { (Boudreaux, 2010) }\end{array}$ \\
\hline Participation & $\begin{array}{l}\text { Producer organization } \\
\text { facilitates farmer } \\
\text { participation (Bacon, } \\
\text { 2005; Moberg, 2005; } \\
\text { Raynolds et al., 2004; } \\
\text { Renard, 2005; Taylor, } \\
\text { 2005; Utting, 2009) and } \\
\text { non-discrimination } \\
\text { standard improves } \\
\text { participation of women } \\
\text { (Bassett, 2010; Lyon et } \\
\text { al., 2010; Ronchi, 2002; } \\
\text { Utting, 2009; Utting- } \\
\text { Chamorro, 2005) }\end{array}$ & $\begin{array}{l}\text { Democratic producer } \\
\text { organization facilitates } \\
\text { farmer participation } \\
\text { (Milford, 2004; Birchall, } \\
\text { 2003, 2004; Majee \& } \\
\text { Hoyt, 2009) including } \\
\text { participation of women } \\
\text { (author's hypothesis) }\end{array}$ & $\begin{array}{l}\text { No change in male or } \\
\text { female farmer } \\
\text { participation because } \\
\text { private management } \\
\text { does not include } \\
\text { mechanism for } \\
\text { participation (authors' } \\
\text { hypothesis) }\end{array}$ \\
\hline
\end{tabular}

\section{COFFEE PRODUCTION IN RWANDA}

We focus on coffee as it was the first product to become Fair Trade certified (Raynolds et al., 2004) and therefore has the longest experience with certification. Rwanda has one of the highest numbers of Fair Trade certified coffee producer organizations in Africa (FLO-CERT, 2010). The country is highly dependent on export revenue from coffee-coffee exports accounted for 36 per cent of Rwanda's total export revenue in 2009 (Boudreaux, 2010). Approximately 400,000 smallholder farmers in Rwanda grow coffee on less than 29,000 hectares of land (OCIR Café, 2009). Though cash crops such as coffee are generally male-dominated while women produce food crops, coffee has become an increasingly important source of income 
for women since the 1994 genocide in Rwanda. The number of women coffee farmers in Rwanda has increased 25 percent since 1992 (Verwimp \& Nillesen, 2007) to 30 percent of the nation's coffee farmers in 2009 (OCIR Café, 2009).

Given the nation's dependence on coffee, changes in coffee production have the potential to affect the social capital of Rwanda's population. Building social capital is important for Rwanda as a means of achieving development in the wake of civil war and genocide (FredMensah, 2004; Mukamunana \& Brynard, 2005; Vervisch, 2011). The trust dimension of social capital (both trust between neighbors and trust toward institutions) has been identified in particular as critical for reconstruction of the nation (Schneider, 2005).

The majority of coffee produced in Rwanda is 'ordinary' grade coffee-low quality coffee indistinguishable by production process or origin traded on the New York Board of Trade "C" market for use in canned pre-ground coffees and for blending. Farmers handpick the coffee cherries during the annual harvest period and de-pulp them manually then lay the coffee parchment in the sun to dry. Farmers sell dried coffee parchment to local traders who in turn sell it to several hulling units in Kigali that process the coffee further, removing the parchment and turning the coffee into green coffee ready for export (IFAD, 2005).

Retail sales of ordinary coffee have stagnated since 1995, while specialty coffee sales have been growing steadily (Byers, Giovannucci, \& Liu, 2008). Specialty coffees are characterized by unique flavor, origin, high quality, or certification (such as Fair Trade certification). Instead of being traded on the "C" market, purchase of specialty coffees is negotiated by import and export operators with the coffee producers or producer organizations at a higher and generally more stable price than ordinary coffee (Berndt, 2007). In 2002, the Government of Rwanda started facilitating a shift from producing low quality, ordinary grade 
coffee to producing fully washed coffee (Ministry of Agriculture and Animal Husbandry \& Ministry of Trade and Industry, 2008). Fully washed coffees tend to be of higher quality and to receive higher prices than ordinary coffee. Some fully washed coffees can be considered specialty coffee.

To produce fully washed coffee, Rwandan producers sell their coffee cherries to coffee washing stations (CWS) for processing instead of manually processing the cherries at home. Normally a farmer will sell his/her high quality cherries to a coffee washing station, and process the rest of his/her cherries at home and sell them as coffee parchment to a local trader (as depicted in Figure 1). Coffee washing stations in Rwanda are either privately owned by entrepreneurs or owned by producer cooperatives. Private owners of washing stations buy coffee cherries from private farmers who did not invest in the processing equipment (Murekezi \& Loveridge, 2009). Other producers join in cooperatives to pool their resources to build a coffee washing station. These cooperatively owned washing stations buy cherries from the farmers who are also part owners of the station (Boudreaux, 2010). Twenty percent of the country's 400,000 coffee growers belong to one of the 148 coffee cooperatives in Rwanda. Fourteen of the nation's coffee cooperatives have Fair Trade certification (OCIR Café, 2009), representing approximately 7,500 coffee farmers. These farmers are required to meet Fair Trade standards, including the social standards. 


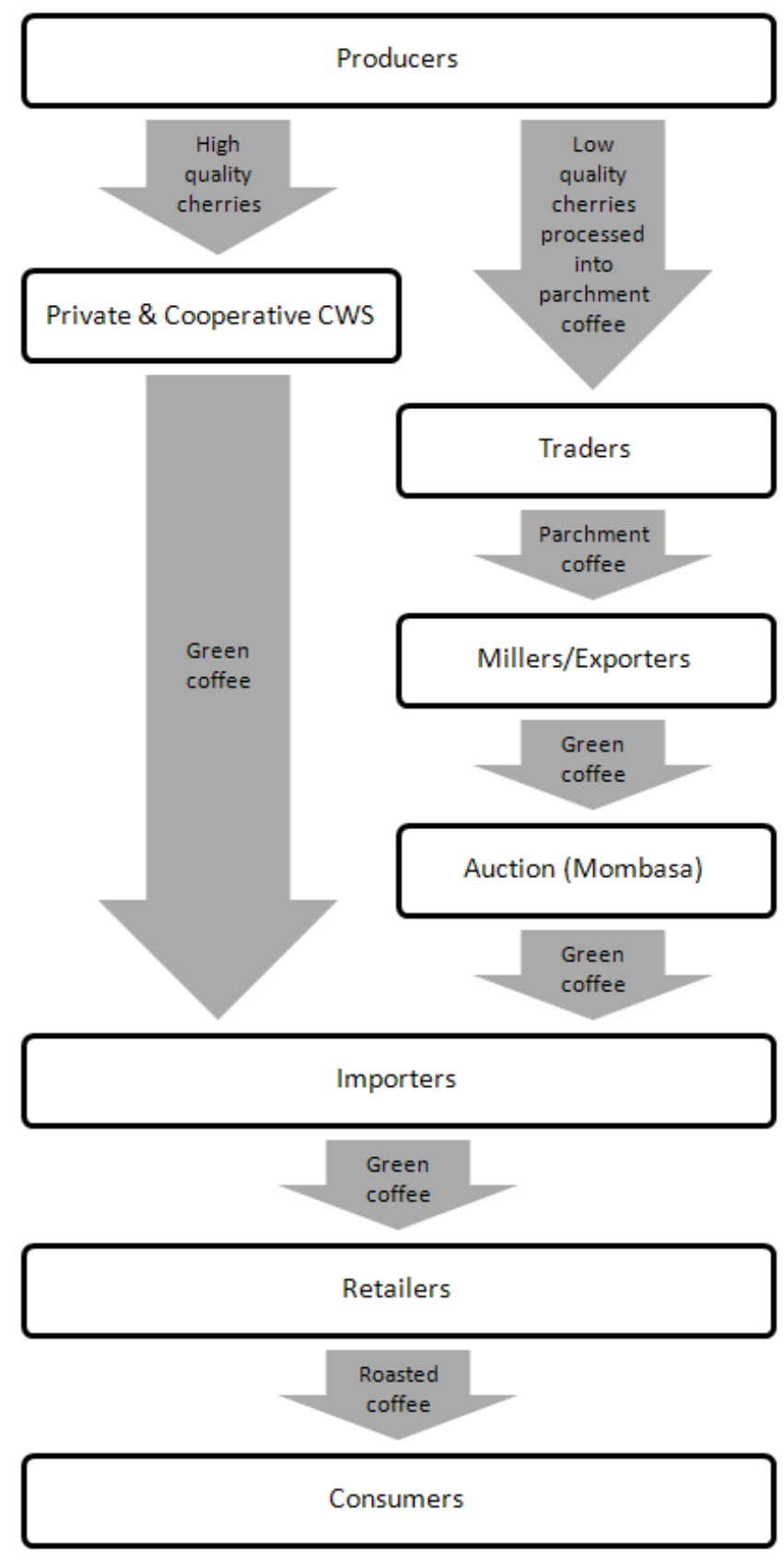

Figure 1: Rwandan coffee chain from crop to cup

\section{METHODS}

(a) Data collection

In order to improve understanding of the effects of Fair Trade certification on social capital, we conducted semi-structured interviews with 30 coffee farmers, surveyed 175 coffee 
farmers, and interviewed 12 coffee sector informants in Rwanda between September and December in 2009. We used the survey to identify farmer perceptions as well as their prevalence, and we used the interview data both to design the questionnaire and to explain the perceptions that arose in the questionnaire. We were able to compare the survey data with the farmer interview responses and the informant interviews in order to improve our understanding of the multiple causes influencing our analysis results.

The study sample included Fair Trade certified cooperative members, non-Fair Trade certified cooperative members, and farmers who do not belong to a cooperative but who sell to a privately-owned CWS. All Fair Trade certified coffee produced in Rwanda is wet processed. Thus, in order to control for coffee origin, quality, and processing method, we sampled only noncertified cooperative and private farmers producing fully washed coffee (i.e. selling to a CWS).

We purposively selected four Fair Trade certified cooperatives for longest length of experience with Fair Trade certification. Among the selected Fair Trade cooperatives, two were certified as Fair Trade in 2004, one in 2005, and another in 2006. All these cooperatives were established between 1999 and 2002, and all received assistance in obtaining Fair Trade certification. The United States Agency for International Development (USAID), the United Nations International Fund for Agricultural Development (IFAD), ACDI-VOCA, Michigan State University, and the Texas A\&M University Norman Borlaug Institute of International Agriculture were involved in supporting the certification process in Rwanda. We sampled two non-Fair Trade certified coffee farmer cooperatives established around the same time as the Fair Trade certified cooperatives, between 2000 and 2005. To avoid a possible bias in agroecological conditions and foreign assistance, we selected non-Fair Trade cooperatives near to the Fair Trade cooperatives that also had support from foreign organizations. We selected a privately owned 
coffee washing station, again in a geographically similar location to the Fair Trade cooperatives and with foreign assistance. USAID, IFAD, ACDI-VOCA, Michigan State University, and Texas A\&M University, as well as Technoserve and the Clinton Hunter Development Initiative, have provided technical assistance, training, and financial support to non-certified cooperative and private coffee washing stations.

Since rural Rwandan households do not have addresses, using organizations' membership lists as a sampling frame to randomly select individual members of the cooperatives and private station was logistically very difficult. Instead, since coffee washing stations are located in areas dominated by coffee production, we approached households and ensured that they did grow coffee and sold to the sampled cooperative or private CWS before starting the survey or interview. To control for distance to the CWS, we sampled farmers in different umudugudu (neighborhoods) of varying proximity to the sampled cooperative or private coffee washing station. We cross-checked whether farmers' declared supply chains were correct in interviews with NGOs, coffee buyers, and government. Nine farmers in our sample sold over 50 percent of their coffee cherries to a CWS other than their own, because their cooperative lacked money to buy cherries at harvest time or because they could get a higher price elsewhere. We kept these farmers in our sample because their exclusion from the analysis did not significantly change the results for cooperative and Fair Trade variables. 


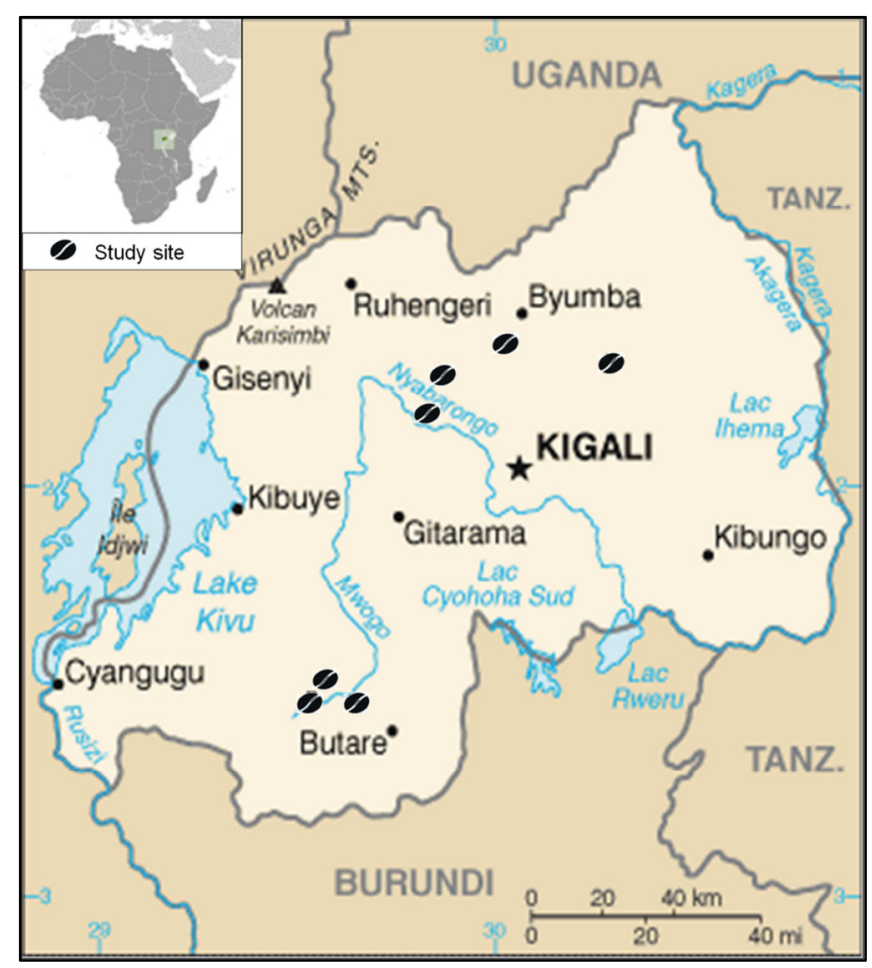

Figure 2: Location of sample sites in Rwanda

We conducted initial visits to each of the sampled organizations to carry out one-on-one semi-structured interviews with four or five farmers in each location, completing a total of 30 interviews. The interviews gathered data on local definitions of well-being, the process of coffee production, and the overall context of producer organizations in Rwanda. The interview data was used to develop a context-appropriate questionnaire, which was then pre-tested, revised, translated from English into Kinyarwanda (the local language in Rwanda), and subsequently back translated into English to ensure the Kinyarwanda translation captured the intended meaning of the questions. The survey collected data on social capital, socioeconomics, and Fair Trade certification from 25 coffee growers from each of the seven sampled organizations.

We also conducted twelve open-ended interviews with key coffee industry informants throughout our research in Rwanda. We interviewed the executives of two local coffee roasting 
companies, representatives of two foreign coffee roasting companies, a Rwandan government official, a coffee industry consultant, and personnel from several different non-governmental organizations with coffee-related projects in Rwanda, including from two Fair Trade organizations. Through these interviews we were able to gain data on Fair Trade certification, coffee cooperatives, and coffee production which helped to shape an understanding of the coffee sector in Rwanda in its entirety, and to contextualize the responses received from the farmer interviews and questionnaires.

This article focuses on four survey indicators used to measure farmer-level dimensions of social capital consistent with the structural/cognitive definition of social capital using questions adapted from the World Bank's Social Capital Integrated Questionnaire (SCIQ) (Grootaert et al., 2004). These four indicators acted as dependent variables for the study analysis: (1) perceived trust among community members; (2) trust in cooperative/CWS leadership; (3) perceived increase in the participation of farmers in cooperative/CWS decision making relative to when the respondent joined his/her cooperative or starting to sell to the private CWS; and, (4) perceived increase in the participation of women in cooperative/CWS decision making relative to when the respondent joined his/her cooperative or starting to sell to the private CWS. Perceived trust and perceived increases in participation represent increased social capital.

Based on the Trust and Solidarity section of the World Bank SCIQ, we measured the cognitive dimension of social capital by asking respondents whether they thought there was generally trust between members of their neighborhood, and by asking whether they trust different types of people, in this case their cooperative or CWS leadership (Grootaert et al., 2004). For cooperative members, leadership refers to the cooperative board, while for private farmers selling to a privately owned coffee washing station leadership refers to the station owner. 
The cooperative boards and the private owner impact farmers' lives similarly by managing the operations of the CWS. As in the World Bank SCIQ, we used active participation in group decision making (as opposed to simply group membership) as an indicator of the structural dimension of social capital, and asked respondents to compare current participation with participation prior to a major event, in this case the time when the respondent joined the cooperative or started selling to the private CWS (Grootaert et al., 2004). Table 2 summarizes the dependent variables.

\section{Table 2: Indicators of social capital}

\section{Social capital Indicator Survey question}

\begin{tabular}{lll}
\hline $\begin{array}{l}\text { Cognitive } \\
\text { dimension }\end{array}$ & $\begin{array}{l}\text { Perceived trust among } \\
\text { community members }\end{array}$ & $\begin{array}{l}\text { Open-ended question asking whether the } \\
\text { respondent perceived trust among the members of } \\
\text { his/her community, later coded as a binary yes/no } \\
\text { response }\end{array}$
\end{tabular}

Trust in cooperative/CWS Yes/no question asking whether the respondent leadership trusts his/her cooperative or CWS leadership

\begin{tabular}{lll}
\hline $\begin{array}{l}\text { Structural } \\
\text { dimension }\end{array}$ & $\begin{array}{l}\text { Perceived increase in } \\
\text { farmer participation in } \\
\text { cooperative/CWS decision } \\
\text { making }\end{array}$ & $\begin{array}{l}\text { Yes/no question asking the respondent whether } \\
\text { he/she perceived an increase in the level of } \\
\text { participation of farmers in cooperative/CWS } \\
\text { decision making since he/she joined the } \\
\text { cooperative or starting selling to the CWS }\end{array}$ \\
\end{tabular}

Perceived increase in $\quad$ Yes/no question asking the respondent whether women's participation in he/she perceived an increase in the level of cooperative/CWS decision participation of women farmers in making cooperative/CWS decision making since he/she joined the cooperative or starting selling to the CWS 
(b) Modeling Fair Trade and cooperative effects on social capital

As discussed above, previous studies in this area did not distinguish between Fair Trade certification and cooperative organization absent Fair Trade as explanatory variables. In order to do so, we have conducted a regression analysis to distinguish between these two explanators of social capital, while controlling for various other factors that could have an influence. We used logistic regressions to estimate relationships between the different forms of producer social organization and dimensions of social capital. The logit model is:

$\mathrm{P}=1 /\left(1+\mathrm{e}^{-\mathrm{Y}}\right)$

where $P$ is the probability that a respondent perceives increased social capital, measured separately by each of the four binary dependent variables (perceived trust among community, trust in leaders, perceived increase in farmer participation, and perceived increase in participation of women), $e$ is a constant, and $Y$ is the log odds of the dependent variable, given by $\mathrm{Y}=\ln (\mathrm{P} / 1-\mathrm{P})$ and assumed to be linearly related to the independent variables (Kutner, Neter, Nachtsheim, \& Li, 2004).

There are two models for each dependent variable. The first model (Model a) includes all observations and the explanatory variable 'coop' specifying whether the producer is a member of a cooperative or not:

$\mathrm{Y}=\beta_{0}+\beta_{1}$ age $+\beta_{2}$ gender $+\beta_{3} \mathrm{hh}+\beta_{4}$ married $+\beta_{5}$ edu $\_\mathrm{d} 1+\beta_{6}$ edu_d $2+\beta_{7}$ years $+\beta_{8}$ income $+\beta_{9}$ price + $\beta_{10}$ productivity $+\beta_{11}$ workload $+\beta_{12}$ training $+\beta_{13}$ interact $+\beta_{14}$ coop 
The second model (Model b) includes only observations for cooperative members and the explanatory variable 'ft' specifying whether the producer's cooperative is Fair Trade certified or not:

$\mathrm{Y}=\beta_{0}+\beta_{1}$ age $+\beta_{2}$ gender $+\beta_{3} \mathrm{hh}+\beta_{4}$ married $+\beta_{5}$ edu $\_\mathrm{d} 1+\beta_{6}$ edu_d $2+\beta_{7}$ years $+\beta_{8}$ income $+\beta_{9}$ price + $\beta_{10}$ productivity $+\beta_{11}$ workload $+\beta_{12}$ training $+\beta_{13}$ interact $+\beta_{14} \mathrm{ft}$

where age indicates the age of the head of household, gender indicates the gender of the head of household (female=1), $h h$ is the number of people in the household, married is whether the head of household is married or not (married $=1), e d u \_d 1$ and $e d u \_d 2$ are dummy variables referring to whether the household head has primary education or secondary education and above respectively, years is the number of years the respondent has been selling to the current CWS, income is income from coffee sales at the 2009 harvest, price is the price the respondent received from his/her CWS per kilogram of coffee cherries at the 2009 harvest, productivity is whether the number of cherries per coffee tree has increased or not since starting to sell to the current CWS (increased=1), workload indicates whether the amount of work it takes to plant, maintain, and harvest coffee has increased or not increased since starting to sell to the current CWS (increased=1), training indicates whether the head of household received training from his or her cooperative or CWS (received training=1), and interact is whether the respondent's interaction with community members increased or not since selling to the current CWS (see Table 3 for a brief description of all the variables used for estimation). $\beta_{0}$ is the intercept, the value of $Y$ when the value of all independent variables is 0 , and $\beta_{1}, \beta_{2}$, etc. indicate the weight of each independent variable's influence on the dependent variable $Y$. The models estimate the odds 
ratios, $\mathrm{e}^{\beta}$. The odds ratio expresses the likelihood of change in the dependent variable given a one unit increase in the independent variable (Kutner et al., 2004).

The model allows us to isolate the independent effect of certification/cooperatives on social capital by including other important variables. We included age in the model as it can have generational effects on trust and civic engagement (Putnam, 1995). We included gender to factor out effects of gender discrimination on social capital. Successful marriage has been statistically associated with higher social capital in North America (Putnam, 1995), so we included whether a respondent is married or not in this model to examine its effects. We included household size because family networks affect social capital (Putnam, 1995). Education can have a powerful effect on trust and participation, thus we included it in the model (Verba et al., 1995). We included whether a producer has received training from a cooperative or CWS as we hypothesize it will have a similar effect as formal education. We expected length of time a respondent has been a member of their group to correlate with greater group participation. Increasing incomes of the rural poor is a dominant policy objective in most developing countries, so we included income to assess whether it affects social capital. We also included price and changes in coffee tree productivity in the model to test whether the economic benefits of certification have an endogenous impact on social capital. Although Robinson (1990) found that time pressure is not associated with social capital, we included whether the amount of work it takes a respondent to maintain, harvest, and process coffee has decreased since joining their group in the model because farmer interviews suggested that increased farmer participation is partly explained by more time due to a reduced workload. We also included in the model frequency of a respondent's interaction with his/her or her neighbors, regardless of whether they belong to the same cooperative or CWS, since farmer interviews indicated it affects social capital. 
Table 3: Sample statistics for logit regression

\begin{tabular}{|c|c|c|c|c|c|c|}
\hline Variable & Description & Obs & Mean & Std. Dev. & Min & Max \\
\hline \multicolumn{7}{|l|}{ Dependent } \\
\hline trust_community & $\begin{array}{l}\text { Perceived trust among } \\
\text { community members, } 1=\text { trust, } \\
0=\text { no trust }\end{array}$ & 154 & .831 & .376 & 0 & 1 \\
\hline trust_leaders & $\begin{array}{l}\text { Trust in cooperative/CWS } \\
\text { leaders, } 1=\text { trust, } 0=\text { no trust }\end{array}$ & 168 & .738 & .441 & 0 & 1 \\
\hline participation & $\begin{array}{l}\text { Perceived increase in } \\
\text { participation of farmers, } \\
1=\text { increased participation, } \\
0=\text { no increase }\end{array}$ & 162 & .370 & .484 & 0 & 1 \\
\hline participation_w & $\begin{array}{l}\text { Perceived increase in } \\
\text { participation of women, } \\
1=\text { increased participation, } \\
0=\text { no increase }\end{array}$ & 163 & .528 & .501 & 0 & 1 \\
\hline \multicolumn{7}{|l|}{ Independent } \\
\hline age & Age of respondent (years) & 168 & 42.5 & 10.5 & 18 & 81 \\
\hline gender & $\begin{array}{l}\text { Gender of respondent, } \\
1=\text { female, } 0=\text { male }\end{array}$ & 163 & .362 & .482 & 0 & 1 \\
\hline hh & Household size & 165 & 6.042 & 2.182 & 1 & 12 \\
\hline married & $\begin{array}{l}\text { Married, } 1=\text { married, } 0=\text { not } \\
\text { married }\end{array}$ & 169 & .812 & .393 & 0 & 1 \\
\hline edu_d1 & $\begin{array}{l}\text { Primary education, Dummy, } \\
1=\text { primary education, } 0=\text { no } \\
\text { education }\end{array}$ & 168 & .637 & .482 & 0 & 1 \\
\hline edu_d2 & $\begin{array}{l}\text { Secondary education and } \\
\text { above, Dummy, } 1=\text { secondary } \\
\text { education and above, } 0=\text { no } \\
\text { education }\end{array}$ & 168 & .119 & .325 & 0 & 1 \\
\hline Years & $\begin{array}{l}\text { Years selling to current } \\
\text { cooperative or private CWS }\end{array}$ & 164 & 5.006 & 2.48 & 1 & 10 \\
\hline Income & $\begin{array}{l}\text { Income from coffee sales at } \\
\text { last harvest (RWF) }\end{array}$ & 168 & 94248 & 126059 & $\begin{array}{r}288 \\
0 \\
\end{array}$ & 800000 \\
\hline Price & $\begin{array}{l}\text { Price from CWS for coffee } \\
\text { cherries at last harvest (RWF) }\end{array}$ & 165 & 125 & 11.79 & 100 & 170 \\
\hline Productivity & $\begin{array}{l}\text { Amount of cherries per coffee } \\
\text { tree, } 1=\text { increased, } 0=\text { no } \\
\text { increase }\end{array}$ & 161 & .789 & .409 & 0 & 1 \\
\hline Workload & $\begin{array}{l}\text { Work to produce coffee, } \\
1=\text { decreased, } 0=\text { no decrease }\end{array}$ & 169 & .858 & .350 & 0 & 1 \\
\hline Training & $\begin{array}{l}\text { Respondent received training } \\
\text { from CWS, } 1=\text { training, } 0=\text { no } \\
\text { training }\end{array}$ & 167 & .617 & .488 & 0 & 1 \\
\hline interact & Interaction with community & 166 & .379 & .487 & 0 & 1 \\
\hline
\end{tabular}




\begin{tabular}{lllllll}
\hline & $\begin{array}{l}\text { members, } 1=\text { increased, } 0=\text { no } \\
\text { increase }\end{array}$ & & & & & \\
\hline Coop & $\begin{array}{l}\text { Cooperative member, 1=yes, } \\
0=\text { no }\end{array}$ & 169 & .852 & .356 & 0 & 1 \\
\hline Ft & $\begin{array}{l}\text { Fair Trade certification, } \\
1=y e s, 0=\text { no }\end{array}$ & 144 & .674 & .470 & 0 & 1 \\
\hline
\end{tabular}

\section{RESULTS}

(a) Summary statistics

We conducted statistical tests to determine whether there were differences between the Fair Trade certified cooperative producers, non-certified cooperative producers, and private producers, and aside from their ownership structure and certification, the three groups of farmers are generally comparable (see Table 4). The proportion of women does not differ significantly among the groups. Nine percent of the women we sampled in Fair Trade cooperatives are widows, 8.5 percent of the women we sampled in non-certified cooperatives are widows, and none of the women we surveyed in the private CWS are widows. Thirty-five percent of our sample overall is women, while 30 percent of all Rwanda's coffee farmers are women (OCIR Café, 2009). The difference in the number of years farmers have been selling their coffee to their cooperative or private CWS is significant; certified and non-certified cooperative farmers have been members for a similar length of time (approximately six years), but farmers selling to the private entrepreneur have only been doing so for an average of two years. This difference is accounted for in the study analysis by including number of years as an independent variable in the regression analysis. Private CWS farmers own a significantly higher number of coffee trees than Fair Trade certified and non-certified cooperative farmers, yet income from coffee sales is not statistically different between these groups. While not a significant difference, Fair Trade farmers do earn less from coffee sales than non-certified cooperative and private farmers. We 
speculate that this is at least partly a result of Fair Trade certification targeting the poorest farmers.

Table 4: Farmer and farm household characteristics (mean values)

\begin{tabular}{lrrrrr}
\hline \multicolumn{1}{c}{ Variable } & $\begin{array}{c}\text { FT } \\
\text { cooperative } \\
(\mathrm{N}=97)\end{array}$ & $\begin{array}{c}\text { Non-FT } \\
\text { cooperative } \\
(\mathrm{N}=47)\end{array}$ & $\begin{array}{r}\text { Private CWS } \\
(\mathrm{N}=25)\end{array}$ & $\begin{array}{c}\mathrm{F} \\
\text { statistic }\end{array}$ & P value \\
\hline Age & 43 & 41 & 41 & 0.77 & 0.46 \\
\hline Woman & $37 \%$ & $24 \%$ & $48 \%$ & 2.25 & 0.11 \\
\hline Size of household & 5.8 & 6.4 & 6.0 & 0.99 & 0.37 \\
\hline Primary education & $59 \%$ & $70 \%$ & $76 \%$ & 1.12 & 0.12 \\
\hline Secondary education or above & $13 \%$ & $11 \%$ & $8 \%$ & 0.34 & 0.71 \\
\hline Years farming & 21 & 21 & 21 & 0.00 & 1.00 \\
\hline Years a member of the coffee & $6.0 *$ & $5.8^{*}$ & $2.1 * *$ & 26.77 & $<0.001$ \\
cooperative or selling to private & & & & & \\
CWS & & & & & \\
\hline Number of coffee trees & $541^{*}$ & $642^{*}$ & $1165^{* *}$ & 2.65 & 0.07 \\
\hline Income from coffee (RWF) & 77,322 & 93,562 & 90,829 & 1.56 & 0.21 \\
\hline Other income (RWF) & 86,166 & 88,457 & 80,789 & 0.02 & 0.98 \\
\hline
\end{tabular}

* not significantly different from each other

$* *$ significantly different from * values

Note: There is no significant difference among groups for variables except years a farmer has been a member of the cooperative or selling to the private CWS and number of coffee trees.

Table 5 presents the means of the social capital indicators measured in the survey, as well as the results of statistical tests used to determine whether there are differences between the three groups of farmers. Overall, farmers perceive trust among their community members. Nearly all farmers selling to the private coffee washing station appear to trust their coffee washing station owner, and a high percentage of non-certified cooperative members trust the board members of their cooperatives. A much lower proportion of Fair Trade certified cooperative members trust their board members. Whereas Fair Trade certified cooperative members appear to trust less, since they joined their cooperative nearly half of them perceive an increase in participation of the average farmer in the decision making of their cooperative. Non-certified cooperative members 
also perceive an increase in the participation of farmers in coffee-related decision making compared to before they joined their cooperative, whereas only eight percent of private farmers perceive a higher level of participation in their group since they started selling to the CWS. Half of the private farmers do perceive an increase in farmer participation in decision making since they started selling to the CWS. The non-certified cooperative members appear to feel that women have increased participation in cooperative decision making to a similar extent that they believe all farmers have increased participation in decision making. The highest proportion (65 percent) of farmers that perceive an increase in the participation of women in their group belongs to the Fair Trade certified cooperatives.

Table 5: Social capital summary statistics

\begin{tabular}{lrrrrr}
\hline \multicolumn{1}{c}{ Variable } & \multicolumn{1}{c}{$\begin{array}{c}\text { FT } \\
\text { cooperative } \\
(\mathrm{N}=97)\end{array}$} & $\begin{array}{c}\text { Non-FT } \\
\text { cooperative } \\
(\mathrm{N}=47)\end{array}$ & $\begin{array}{l}\text { Private } \\
\text { CWS } \\
(\mathrm{N}=25)\end{array}$ & F statistic & P value \\
\hline $\begin{array}{l}\text { Perceived trust among } \\
\text { community members }\end{array}$ & $81 \%$ & $85 \%$ & $88 \%$ & 0.47 & 0.63 \\
\hline Trust in leaders & $62 \% * *$ & $87 \%^{*}$ & $96 \% *$ & 9.69 & 0.0001 \\
\hline $\begin{array}{l}\text { Perceived increase in } \\
\text { farmer participation }\end{array}$ & $47 \%$ & $32 \%$ & $8 \%$ & 7.09 & 0.0011 \\
\hline $\begin{array}{l}\text { Perceived increase in } \\
\text { participation of women }\end{array}$ & $65 \%^{\mathrm{d}}$ & $27 \%^{\mathrm{e}}$ & $50 \%{ }^{\mathrm{d}}$ & 9.62 & 0.0001 \\
\hline
\end{tabular}

* not significantly different from each other

** significantly different from * values

Note: There is no significant difference among groups for variables except trust in leaders.

(b) Regression results

We used the two logistic regression models outlined above to explore variability in social capital among the three groups of farmers. The models we ran are significant at explaining a large amount of variance in social capital, with model p-values ranging from $<0.00001$ to 0.0423 , and pseudo- $\mathrm{R}^{2}$ in the range of 0.1615 to 0.3405 - values of pseudo- $\mathrm{R}^{2}$ between 0.2 and 0.4 are 
considered indicative of extremely good model fits (Louviere, Hensher, \& Swait, 2000), equivalent to 0.7 to 0.9 for a linear function (Domencich \& McFadden, 1975).

Models $1 \mathrm{a}$ and $1 \mathrm{~b}$ indicate that neither being a member of a cooperative nor having Fair Trade certification is significantly related to variation in farmers' perception of trust among their community members (Table 6). Instead the models link perceived trust among community members most significantly to increased interaction with neighbors. Age, household size, and an education level of secondary school or above are also positively correlated with perceptions of trust among community members. The price of coffee is negatively correlated with perceptions of trust among community members. Whereas cooperative organization and Fair Trade have no effect on farmers' perception of trust among community members (Table 7, Models $2 a$ and $2 b$ ), both being a member of a cooperative and having Fair Trade certification are significantly associated with a lack of trust in leaders. Model $2 b$ shows that Fair Trade certified cooperative members are even less likely to trust their leadership than non-certified cooperative members. Indeed, this association is likely driving the connection between cooperative membership and lack of trust in leadership in model 2a (where Fair Trade cooperative members are grouped with non-certified cooperative members to compare all cooperative members to CWS farmers) since there are a greater number of Fair Trade cooperative members in the study sample than noncertified cooperative members. Additional model runs comparing only non-Fair Trade cooperative members to the private coffee washing station and only Fair Trade cooperative members to the private coffee washing station further supports this hypothesis. The model comparing non certified members to private members was insignificant overall while the model comparing Fair Trade certified cooperative members to the private sellers showed a strong effect of belonging to the cooperative on leadership trust. The longer a farmer has been a member of a 
cooperative and/or had Fair Trade certification, the less likely he/she is to trust the leadership.

The higher the price a cooperatively-organized farmer received for his/her coffee, the less likely

he/she is to trust the cooperative board. Although, if a farmer is older, has received training from the cooperative or coffee washing station, interacts more with his/her neighbors, has experienced a decrease in the amount of work it takes to produce, harvest, and process coffee, and has seen an increase in the productivity of his/her coffee trees, he/she seems more likely to trust the cooperative board members or coffee washing station owner.

Table 6: Logistic regression models explaining variation in perceived trust among community members. Model 1a: Perceived trust among community members, Cooperative versus non-cooperative. Model 1b: Perceived trust among community members, Fair Trade cooperative versus non-Fair Trade cooperative.

\begin{tabular}{|c|c|c|c|c|}
\hline Variable & \multicolumn{2}{|c|}{ Model 1a } & \multicolumn{2}{|c|}{ Model $1 \mathrm{~b}$} \\
\hline & Odds ratio $^{\mathrm{a}}$ & Standard error & Odds ratio & Standard error \\
\hline age & $1.0564 *$ & 0.0328 & $1.0751^{*}$ & 0.0414 \\
\hline gender & 1.8837 & 1.1685 & 2.8483 & 2.2118 \\
\hline hh & $1.2841^{*}$ & 0.1847 & $1.3383^{*}$ & 0.2150 \\
\hline married & 0.4635 & 0.3698 & 0.3541 & 0.3255 \\
\hline edu_d1 & 2.2970 & 1.5746 & 2.8663 & 2.2811 \\
\hline edu_d2 & 5.5450 & 6.1772 & 9.4896* & 11.846 \\
\hline years & 1.0761 & 0.1406 & 0.9964 & 0.1468 \\
\hline income & 1.0000 & $3.39 \mathrm{E}-06$ & 1.0000 & $3.73 \mathrm{E}-06$ \\
\hline price & $0.9567 *$ & 0.0220 & $0.9374 *$ & 0.0293 \\
\hline productivity & 0.7793 & 0.6125 & 2.2665 & 2.0690 \\
\hline workload & 1.8749 & 1.5403 & 3.7451 & 3.9569 \\
\hline training & 1.1889 & 0.6947 & 1.6733 & 1.0747 \\
\hline interact & $5.8152 * *$ & 4.1186 & $12.173 * * *$ & 11.175 \\
\hline coop & 0.3483 & 0.3476 & & \\
\hline \multirow[t]{4}{*}{$\mathrm{ft}$} & & & 1.3811 & 1.1914 \\
\hline & $\mathrm{N}=128$ & & $\mathrm{~N}=104$ & \\
\hline & $\begin{array}{l}\text { Prob }>\text { chi2 }= \\
0.0423\end{array}$ & & $\begin{array}{l}\text { Prob }>\text { chi } 2= \\
0.0081\end{array}$ & \\
\hline & Pseudo $R^{2}=$ & & $\begin{array}{l}\text { Pseudo } R^{2}= \\
0.2849\end{array}$ & \\
\hline
\end{tabular}

$* p<0.1 * * p<0.05$ and $* * * p<0.01$

${ }^{a}$ The odds ratio expresses the likelihood of change in the dependent variable given a one unit increase in the independent variable. An odds ratio $>1$ indicates that an increase in that variable is associated with an increased likelihood of perceived trust among community members. An 
odds ratio $<1$ indicates that an increase in that variable is associated with a decreased likelihood of perceived trust among community members. For example, a respondent who has increased interaction is 5.8 times more likely to trust his or her leaders than a respondent who had not experienced an increase in interaction.

Table 7: Logistic regression models explaining variation in trust in leaders. Model 2a: Trust in leaders, Cooperative versus non-cooperative. Model 2b: Trust in leaders, Fair Trade cooperative versus non-Fair Trade cooperative.

\begin{tabular}{|c|c|c|c|c|}
\hline \multirow[t]{2}{*}{ Variable } & \multicolumn{2}{|c|}{ Model 2a } & \multicolumn{2}{|c|}{ Model 2b } \\
\hline & Odds ratio $^{\mathrm{a}}$ & Standard error & Odds ratio & Standard error \\
\hline age & $1.0785 * *$ & 0.0336 & $1.1323 * *$ & 0.0431 \\
\hline gender & 1.4680 & 0.9137 & 1.1927 & 0.8021 \\
\hline hh & 1.0955 & 0.1351 & 0.9934 & 0.1352 \\
\hline married & 0.9997 & 0.7148 & 0.5627 & 0.4776 \\
\hline edu_d1 & 0.8638 & 0.5755 & 1.0182 & 0.7375 \\
\hline edu_d2 & 2.2642 & 1.9548 & 2.8427 & 2.7020 \\
\hline years & $0.7642 * *$ & 0.0988 & $0.7808^{*}$ & 0.1091 \\
\hline income & 1.0000 & $2.25 \mathrm{E}-06$ & 1.0000 & $2.56 \mathrm{E}-06$ \\
\hline price & $0.9456 * * *$ & 0.0196 & 0.9802 & 0.0252 \\
\hline productivity & $9.5059 * * *$ & 7.3991 & $10.938 * * *$ & 10.159 \\
\hline workload & 3.0799 & 2.4072 & $5.5731 *$ & 5.2205 \\
\hline training & $3.4587 * *$ & 1.8810 & $2.7991 *$ & 1.6503 \\
\hline interact & $3.3461 * *$ & 2.0262 & $3.8405 * *$ & 2.4532 \\
\hline coop & $0.0127 * * *$ & 0.0178 & & \\
\hline $\mathrm{ft}$ & & & $0.1092 * *$ & 0.0978 \\
\hline & $\mathrm{N}=137$ & & $\mathrm{~N}=113$ & \\
\hline & $\begin{array}{l}\text { Prob }>\text { chi } 2= \\
0.0001\end{array}$ & & $\begin{array}{l}\text { Prob }>\text { chi } 2= \\
0.0000\end{array}$ & \\
\hline & Pseudo $\mathrm{R}^{2}=0.2924$ & & Pseudo $\mathrm{R}^{2}=0.3405$ & \\
\hline
\end{tabular}

$* p<0.1 * * p<0.05$ and $* * * p<0.01$

${ }^{\text {a }}$ See notes to Table 6 for an explanation of odds ratio.

Cooperative membership is significantly associated with farmers perceiving, since they joined their cooperative, an increase in the participation of the average farmer in decisions (Table 8, Model 3a). Whether the cooperative is Fair Trade certified or not is not significant (Table 8, Model 3b). Membership in a cooperative versus selling to a private coffee washing station is not associated with perceptions of an increase in participation of women, but Fair Trade certification 
is linked to farmer perception of increased participation of women (Table 9, Models 4a and 4b). Interaction with neighbors is more significantly linked to a perceived increase in farmer participation than cooperative organization. Farmers seem eight times more likely to perceive that participation of farmers in making decisions has increased if they themselves have increased interaction with their neighbors. If a farmer has increased interaction with his/her neighbors, he/she appears four times more likely to perceive an increase in the participation of women since he/she joined his/her cooperative or started to sell to his/her CWS. Being married has a strong negative association with whether farmers feel there is increased participation of farmers in decisions. If a farmer has some education (primary school) and if he/she has seen a decrease in the amount of work it takes to grow coffee, he/she is more likely to feel that there is increased farmer participation in decisions. Table 10 summarizes the different models and their findings. 
Table 8: Logistic regression models explaining variation in perceived higher participation of all farmers. Model 3a: Perceived increase in farmer participation, Cooperative versus non-cooperative. Model 3b: Perceived increase in farmer participation, Fair Trade cooperative versus non-Fair Trade cooperative.

\begin{tabular}{|c|c|c|c|c|}
\hline \multirow[t]{2}{*}{ Variable } & \multicolumn{2}{|c|}{ Model 3a } & \multicolumn{2}{|c|}{ Model 3b } \\
\hline & Odds ratio $^{\mathrm{a}}$ & Standard error & Odds ratio & Standard error \\
\hline age & 1.0349 & 0.0247 & $1.0490^{*}$ & 0.0281 \\
\hline gender & 1.2085 & 0.6502 & 1.0433 & 0.6154 \\
\hline hh & 0.9648 & 0.1138 & 0.9104 & 0.1157 \\
\hline married & $0.2327 * *$ & 0.1681 & $0.1636 * *$ & 0.1317 \\
\hline edu_d1 & $3.0790 *$ & 2.0918 & $3.5647^{*}$ & 2.6518 \\
\hline edu_d2 & 2.4556 & 2.0236 & 3.0810 & 2.6937 \\
\hline years & 1.0624 & 0.1176 & 1.0828 & 0.1270 \\
\hline income & 1.0000 & $2.03 \mathrm{E}-06$ & 1.0000 & $2.20 \mathrm{E}-06$ \\
\hline price & 1.0221 & 0.0210 & 1.0236 & 0.0255 \\
\hline productivity & 0.5873 & 0.4188 & 0.5395 & 0.4270 \\
\hline workload & 5.2094* & 4.8140 & $6.2113^{*}$ & 6.1945 \\
\hline training & 0.9309 & 0.4659 & 0.5638 & 0.3065 \\
\hline interact & $8.0948 * * *$ & 4.0230 & $8.3695 * * *$ & 4.5314 \\
\hline coop & $8.9612 * *$ & 8.5920 & & \\
\hline $\mathrm{ft}$ & & & 1.0056 & 0.6808 \\
\hline & $\mathrm{N}=131$ & & $\mathrm{~N}=107$ & \\
\hline & $\begin{array}{l}\text { Prob }>\text { chi } 2= \\
0.0000\end{array}$ & & $\begin{array}{l}\text { Prob }>\text { chi } 2= \\
0.0005\end{array}$ & \\
\hline & Pseudo $\mathrm{R}^{2}=0.2823$ & & $\begin{array}{l}\text { Pseudo } \mathrm{R}^{2}= \\
0.2628\end{array}$ & \\
\hline
\end{tabular}

$* p<0.1 * * p<0.05$ and $* * * p<0.01$

${ }^{\text {a }}$ See notes to Table 6 for an explanation of odds ratio. 
Table 9: Logistic regression models explaining variation in higher participation of women farmers. Model 4a: Perceived increase in participation of women, Cooperative versus noncooperative. Model 4b: Perceived increase in participation of women, Fair Trade cooperative versus non-Fair Trade cooperative.

\begin{tabular}{|c|c|c|c|c|}
\hline \multirow[t]{2}{*}{ Variable } & \multicolumn{2}{|c|}{ Model 4a } & \multicolumn{2}{|c|}{ Model 4b } \\
\hline & Odds ratio $^{\mathrm{a}}$ & Standard error & Odds ratio & Standard error \\
\hline age & 1.0339 & 0.0224 & 1.0352 & 0.0253 \\
\hline gender & 0.9216 & 0.4201 & 0.7129 & 0.3980 \\
\hline hh & 0.8760 & 0.0922 & 0.8867 & 0.1053 \\
\hline married & 0.4375 & 0.2777 & 0.4046 & 0.2868 \\
\hline edu_d1 & 2.3435 & 1.3006 & 2.0051 & 1.2550 \\
\hline edu_d2 & 1.6907 & 1.2247 & 2.4945 & 2.0654 \\
\hline years & 1.1750 & 0.1282 & 1.0982 & 0.1316 \\
\hline income & 1.0000 & 0.0000 & 1.0000 & 0.0000 \\
\hline price & $1.0394 *$ & 0.0208 & 1.0160 & 0.0249 \\
\hline productivity & $0.2935^{*}$ & 0.1853 & 0.5146 & 0.4222 \\
\hline workload & 2.0188 & 1.2416 & 2.2930 & 1.7218 \\
\hline training & 0.9183 & 0.4067 & 0.8128 & 0.4121 \\
\hline interact & $4.1422 * * *$ & 1.8499 & $4.4371 * * *$ & 2.2080 \\
\hline coop & 1.0680 & 0.7739 & & \\
\hline \multirow[t]{4}{*}{$\mathrm{ft}$} & & & $2.7880^{*}$ & 1.7266 \\
\hline & $N=133$ & & $\mathrm{~N}=110$ & \\
\hline & $\begin{array}{l}\text { Prob }>\text { chi } 2= \\
0.0086\end{array}$ & & $\begin{array}{l}\text { Prob }>\text { chi } 2= \\
0.0033\end{array}$ & \\
\hline & Pseudo $\mathrm{R}^{2}=$ & & $\begin{array}{l}\text { Pseudo } \mathrm{R}^{2}= \\
0.2152\end{array}$ & \\
\hline
\end{tabular}

$* p<0.1 * * p<0.05$ and $* * * p<0.01$

${ }^{\text {a }}$ See notes to Table 6 for an explanation of odds ratio. 
Table 10: Summary of regression models and their findings

\begin{tabular}{|c|c|c|c|}
\hline Model \# & Dependent variable & Comparison & Summary of findings \\
\hline Model 1a & $\begin{array}{l}\text { Perceived trust among } \\
\text { community members }\end{array}$ & $\begin{array}{l}\text { Coop vs. } \\
\text { Non-coop }\end{array}$ & $\begin{array}{l}\text { Age, household size, price, interaction all } \\
\text { significant. Interaction positive and large. }\end{array}$ \\
\hline Model 1b & $\begin{array}{l}\text { Perceived trust among } \\
\text { community members }\end{array}$ & $\begin{array}{l}\text { FT coop vs. } \\
\text { Non-FT coop }\end{array}$ & $\begin{array}{l}\text { Age, household size, education, price, } \\
\text { interaction all significant. Interaction } \\
\text { positive and large. }\end{array}$ \\
\hline Model 2a & Trust in leaders & $\begin{array}{l}\text { Coop vs. } \\
\text { Non-coop }\end{array}$ & $\begin{array}{l}\text { Age, years, training, interaction, price, } \\
\text { productivity, cooperative all significant. } \\
\text { Productivity positive and large. } \\
\text { Cooperative negative and large. }\end{array}$ \\
\hline Model 2b & Trust in leaders & $\begin{array}{l}\text { FT coop vs. } \\
\text { Non-FT coop }\end{array}$ & $\begin{array}{l}\text { Age, years, productivity, workload, } \\
\text { training, interaction, FT all significant. } \\
\text { Productivity positive and large. FT } \\
\text { negative and large. }\end{array}$ \\
\hline Model 3a & $\begin{array}{l}\text { Perceived increase in } \\
\text { farmer participation }\end{array}$ & $\begin{array}{l}\text { Coop vs. } \\
\text { Non-coop }\end{array}$ & $\begin{array}{l}\text { Marriage, education, workload, } \\
\text { interaction, cooperative all significant. } \\
\text { Interaction and cooperative positive and } \\
\text { large. }\end{array}$ \\
\hline Model 3b & $\begin{array}{l}\text { Perceived increase in } \\
\text { farmer participation }\end{array}$ & $\begin{array}{l}\text { FT coop vs. } \\
\text { Non-FT coop }\end{array}$ & $\begin{array}{l}\text { Age, marriage, education, workload, } \\
\text { interaction all significant. Interaction } \\
\text { positive and large }\end{array}$ \\
\hline Model 4a & $\begin{array}{l}\text { Perceived increase in } \\
\text { participation of women }\end{array}$ & $\begin{array}{l}\text { Coop vs. } \\
\text { Non-coop }\end{array}$ & $\begin{array}{l}\text { Price, productivity, and interaction all } \\
\text { significant. Interaction positive and large. }\end{array}$ \\
\hline Model 4b & $\begin{array}{l}\text { Perceived increase in } \\
\text { participation of women }\end{array}$ & $\begin{array}{l}\text { FT coop vs. } \\
\text { Non-FT coop }\end{array}$ & $\begin{array}{l}\text { Interaction and FT significant. Both } \\
\text { positive and large. }\end{array}$ \\
\hline
\end{tabular}

\section{DISCUSSION AND CONCLUSION}

The literature on Fair Trade certification's impacts indicates that the social capital effects of Fair Trade certification may be especially important for producer well-being, due mainly to the cooperative organization of producers. This study aims to improve understanding of whether changes in producer-level social capital are a result primarily of cooperative organization or of Fair Trade certification. The regression analyses provide limited evidence that cooperative organization and Fair Trade certification are both associated with dimensions of social capital, although not always in the ways expected. In addition, the analyses do provide some counterevidence against the relationship. In particular, neither cooperative organization nor Fair Trade 
certification is associated with perceived trust among community members. Even more surprisingly, both cooperative organization and Fair Trade certification have a significant negative association with trust in cooperative board members. Findings regarding perceived increases in farmer participation in decision making are more consistent with the study hypotheses; cooperative membership, regardless of certification, is positively correlated with a perceived increase in farmer participation in decision making, and Fair Trade certification is associated with producers' perceiving that, since they joined their cooperative, women have increased participation in cooperative decision making. This study is a first foray into quantitatively analyzing the relationship between Fair Trade certification and social capital. While the regression results do not provide the direction of the causal relationships between variables, knowing a relationship between two variables exists holding other factors constant, and the strength of that link, provides important insight into what factors, including Fair Trade and cooperative organization, may affect social capital.

The coffee producers surveyed generally perceive that there is trust between their community members, but while they attribute this trust to the existence of cooperatives, the regression results show that whether farmers perceive general trust in the community relates to whether they themselves have frequent interaction with their neighbors and not whether they are a member of a cooperative. In other words, greater interactions related to the mode of coffee production and processing, not cooperatives per se, seem to be building trust. This result would support the promotion of collective coffee processing, such as coffee washing stations, even if private owned. In Rwanda, trust is understood broadly as what Govier and Verwoerd (2002) define as "an attitude of confident expectation" that the person or persons trusted will act in a decent, competent, and acceptable way that does not result in harm to the trusting person. Study 
respondents gave the following as specific examples of trust: the ability to depend on a person for help, whether in the form of advice or a loan; the knowledge that a person will not steal from you; and an understanding of the other person and their motivations. Farmers linked trust among community members to coffee cooperatives. As one coffee grower explained, "Community support has increased a lot because we have seen the benefits of working together. We didn't know before about the benefits of joining together in a cooperative" (Producer IAA003, personal communication, November 2, 2009). Another cooperative member said, "Before the cooperative I spent the whole day at home after work. Now I meet people through the cooperative and meet them to share a bottle of beer and ideas" (Producer IAE001, personal communication, October 27, 2009). Yet another farmer elaborated: "We are able to discuss with others, share ideas, get ideas, learn from them, and don't feel isolated" (Producer IAC003, personal communication, October 27, 2009). The regression results do not show a link between perceived trust among community members and cooperative organization though, and instead suggest that the greater the amount of time he/she has spent interacting with his/her neighbors, and to a small degree the older a farmer is and the larger his/her household is, the more likely he/she is to perceive trust among his/her community members.

Interestingly, while cooperative farmers attribute their increased interaction with neighbors to being a member of a cooperative, producers selling to the privately owned coffee washing station attribute their increased interaction with their neighbors to the coffee washing station. A private farmer observed that "coffee lets us know other people in the area" and the coffee washing station "brings ideas from different people and gives you strength to stand together" (Producer IAB005, personal communication, October 26, 2009). In most cases, private producers seem to equate selling to the privately owned CWS with being a member of a 
cooperative, indicating that private coffee washing stations may play a role similar to the one expected of cooperatives in the lives of coffee farmers in Rwanda. As one producer said, "in general, people in the community have good relationships because people are brought together by coffee" (Producer IAD002, personal communication, October 29, 2009). We are unable to determine for certain the direction of the relationship between increased interaction and increased social capital based on the regression results alone, yet the interview data suggest the possibility that selling to a central processing location can increase interaction among neighbors, regardless of whether the coffee washing station is privately or cooperatively owned. If implemented in a way that increases social interaction, value added activities appear to have the potential to not only increase income but also to improve social capital.

Cooperative organization and Fair Trade certification are not linked to perceived trust among community members, but cooperative organization, and Fair Trade certification especially, are negatively associated with trust in leaders while private coffee washing stations are not, likely because of leaders mismanaging their cooperatives. More than one member from two of the sampled cooperatives testified that their cooperatives had experienced embezzlement of cooperative funds and nepotism by their leaders. Both of these cooperatives had Fair Trade certification. A staff member of a Rwandan coffee company explained that "whether farmers benefit from joining in cooperatives depends largely on the management of the cooperative" (Representative 1, personal communication, December, 2009). It is likely that management also matters in the case of individual farmers selling to a private coffee washing station. This study only included one private CWS, which turned out to be well managed, but which is not necessarily representative of all private CWS in Rwanda. While the results of the cooperative to private CWS comparison need to be treated with some reservation, by including one private 
CWS we are able to give some indication of what can happen when there is a well managed private coffee washing station. There is a need for further research with larger sample sizes to further explore the question of management and leadership trust in Fair Trade cooperatives, nonFair Trade cooperatives, and private coffee washing stations.

The Director of another coffee company in Rwanda suggests that cooperative organization can make it easier for an individual to take advantage of members because they are organized and have a leadership structure they respond to (Representative 2, personal communication, December 7, 2009). In a study of social capital and the Rwandan genocide, Pinchotti and Verwimp (2007) differentiate between bonding and bridging forms of social capital to explain how in the 1990s vertical relationships between the state and the local level (bridging social capital) enabled government authorities to use political and manipulative powers to undermine the horizontal associations between farmers of different ethnic groups (bonding social capital) of the agricultural cooperatives. Similarly, a staff member of an NGO supporting coffee cooperatives in Rwanda explained how he believes the history of colonial rule and dictatorial governments in Rwanda has led to a culture of farmers doing what they are told by authorities without question for fear of the consequences, and that this makes it easy for cooperative managers to act in their own interest instead of the interest of the group. He maintains that capacity building of cooperative members is key to whether members benefit, more so than Fair Trade certification, so that farmers understand the concept of a cooperative and that they own and control the organization (Representative 3, personal communication, December 7, 2009). Indeed, the regression results indicate that farmers who receive training from their cooperative or CWS, who see gains in terms of coffee tree productivity, and who have increased interaction with their neighbors, are more likely to trust their leadership. 
Despite a lack of trust in cooperative board members, farmers that belong to cooperatives appear more likely to perceive an increase in farmer participation in decision making than private farmers. A technician working with coffee cooperatives in Rwanda contends that cooperative farmers are learning and capturing the value of democracy. Having experienced a variety of leadership styles over the years, including corrupt management, cooperative members are beginning to understand that by voting for their choice of board members they can affect the organization's impact on their lives (Representative 3, personal communication, December 7, 2009). It is not surprising that the regressions show no link between private ownership and perceptions of increased farmer participation. There is no mechanism to include farmers in decisions; the entrepreneur who owns the station retains decision making power.

Fair Trade certification does not seem to have an effect on perceptions of an increase in participation of farmers in decision making beyond cooperative membership, but it may increase participation of women. The perception that women have increased participation in decision making in Fair Trade cooperatives was true of both male and female respondents (i.e. perception of women's participation was not determined to the gender of the respondent). This suggests that Fair Trade's non-discrimination standard may have a positive effect on gender relations in Rwanda. Because interaction with neighbors is also significantly related to feelings that women have increased participation, it is likely that farmers are not just saying there is gender equity and that women actually do participate more when they belong to a cooperative with Fair Trade certification. A producer explained that “before women stayed at home and couldn't go out and get ideas. Before they said the cooperative was only for men, but then said women can join and we'll see how they can produce. Now women have their own association within the cooperative that produces the best coffee" (Producer IAF001, personal communication, October 28, 2009). 
Our findings provide new insight into previous research on the social impacts of Fair Trade certification, though the overall effect of Fair Trade on social capital is unclear. Like Pirotte, Pleyers, and Poncelet (2006) and Moberg (2005), we observed that producers develop social networks and a sense of community through shared work and regular meetings, but we suggest that increased interaction with community members plays more of a role in achieving this than Fair Trade certification. While others claim that Fair Trade certification can promote broad producer participation in their cooperative and their community (see Taylor, 2005; Raynolds et al., 2004; Utting, 2009), our analyses suggest that cooperative organization itself may be more responsible for farmer participation than Fair Trade certification. On the other hand, our findings corroborate Bassett (2010) and Utting's (2009) reports that Fair Trade certification encourages women in particular to participate in producer cooperatives.

Many developing nations face the question of whether to invest in product certification and what are the economic, environmental, and social effects of those investments. If our findings are held up by future research, they have important implications for policy and development programs. In the case of Rwanda, the move to processing coffee at coffee washing stations may be leading to social capital benefits for producers. In other words, whereas certification brings access to premium markets and requires formal cooperation processes that may be abused, quality improvement activities that increase interactions may bring access to specialty markets without similar risk of grievances over organizational capture. Pursuit of this question could contribute meaningfully to the debate (see Parrish et al., 2005, for example) over whether certification should be the focus of market-based efforts to improve the well-being of small-scale producers in the developing world. 


\section{REFERENCES}

Arnould, E. J., Plastina, A., \& Ball, D. (2009). Does Fair Trade deliver on its core value proposition? Effects on income, educational attainment, and health in three countries. Journal of Public Policy \& Marketing, 28(2), 186-201.

Bacon, C. (2005). Confronting the coffee crisis: Can Fair Trade, Organic, and specialty coffees reduce small-scale farmer vulnerability in northern Nicaragua? World Development, $33(3), 497-511$.

Baron, S., Field, J., \& Schuller, T. (2000). Social capital: Critical perspectives. Oxford, UK: Oxford University Press.

Bassett, T. J. (2010). Slim pickings: Fairtrade cotton in West Africa. Geoforum, 41(1), 44-55.

Becchetti, L., \& Costantino, M. (2008). The effects of Fair Trade on affiliated producers: An impact analysis on Kenyan farmers. World Development, 36(5), 823-842.

Berndt, C. (2007). Is Fairtrade in coffee production fair and useful? Evidence from Costa Rica and Guatemala and implications for policy. Arlington, VA: Mercatus Center.

Birchall, J. (2003). Rediscovering the cooperative advantage: Poverty reduction through selfhelp. Geneva: International Labour Office.

Birchall, J. (2004). Cooperatives and the Millenium Development Goals. Geneva: International Labour Office.

Boudreaux, K. C. (2010). A better brew for success: Economic liberalization in Rwanda's coffee sector. Arlington, VA: Mercatus Center. Retrieved from http://mercatus.org/publication/better-brew-success 
Byers, A., Giovannucci, D., \& Liu, P. (2008). Value-adding standards in the North American food market: Trade opportunities in certified products for developing countries. Retrieved April 5, 2011, from http://www.fao.org/docrep/010/a1585e/a1585e00.htm

Domencich, T. A., \& McFadden, D. (1975). Urban travel demand: A behavioral analysis. Amsterdam: North-Holland.

FLO-CERT. (2010). Operators. Retrieved April 5, 2011, from http://www.flo-cert.net/flocert/main.php?id=10

FLO. (2010). Annual report 2009-10. Bonn: Fairtrade Labelling Organizations International.

FLO. (2011). Fairtrade standards for coffee for small producers' organizations. Bonn: Fairtrade Labelling Organizations International.

Fred-Mensah, B. K. (2004). Social capital building as capacity for postconflict development: The UNDP in Mozambique and Rwanda. Global Governance, 10(4), 437-457.

Govier, T., \& Verwoerd, W. (2002). Trust and the problem of national reconciliation. Philosophy of the Social Sciences, 32(2), 178-205.

Greene, J. C., Caracelli, V. J., \& Graham, W. F. (1989). Toward a conceptual framework for mixed-method evaluation designs. Educational Evaluation and Policy Analysis, 11(3), 255-274.

Grootaert, C., Narayan, D., Jones, V. N., \& Woolcock, M. (2004). Measuring social capital: An integrated questionnaire. Washington, DC: World Bank.

IFAD. (2005). Smallholder cash and export crop development project. Retrieved April 4, 2010, from http://www.ifad.org/english/operations/pf/rwa/i596rw/web/index.htm 
Imhof, S., \& Lee, A. (2007). Assessing the potential of Fair Trade for poverty reduction and conflict prevention: A case study of Bolivian coffee producers. Bern, Switzerland: Swisspeace.

Jaffee, D. (2007). Brewing justice: Fair trade coffee, sustainability, and survival. Berkley, CA: University of California Press.

Kolk, A. (2011). Mainstreaming sustainable coffee. Sustainable Development, online in advance of print version.

Kolk, A. (2012). Towards a sustainable coffee market: Paradoxes faced by a multinational company. Corporate Social Responsibility and Environmental Management, online in advance of print version.

Kutner, M. H., Neter, J., Nachtsheim, C. J., \& Li, W. (2004). Applied linear statistical models. New York, NY: McGraw Hill Higher Education.

Levi, M., \& Linton, A. (2003). Fair Trade: A cup at a time? Politics \& Society, 31(3), 407-432.

Louviere, J. J., Hensher, D. A., \& Swait, J. D. (2000). Stated choice methods: Analysis and applications. Cambridge, UK: Cambridge University Press.

Lyon, S. (2007). Fair trade coffee and human rights in Guatemala. Journal of Consumer Policy, $30(3), 241-261$.

Lyon, S., Bezaury, J. A., \& Mutersbaugh, T. (2010). Gender equity in fairtrade-organic coffee producer organizations: Cases from Mesoamerica. Geoforum, 41(1), 93-103.

Majee, W., \& Hoyt, A. (2010). Are worker-owned cooperatives the brewing pots for social capital? Community Development, 41(4), 417-430.

Milford, A. (2004). Coffee, co-operatives and competition: The impact of Fair Trade. Retrieved March 4, 2011, from http://www.cmi.no/publications/2004/rep/r2004-6.pdf 
Ministry of Agriculture and Animal Husbandry, \& Ministry of Trade and Industry (2008). Rwanda national coffee strategy 2009-2012. Kigali, Rwanda: Government of Rwanda. Moberg, M. (2005). Fair Trade and eastern Caribbean banana farmers: Rhetoric and reality in the anti-globalization movement. Human Organization, 64(1), 4-15.

Mohan, G., \& Mohan, J. (2002). Placing social capital. Progress in Human Geography, 26(2), $191-210$.

Mukamunana, R., \& Brynard, P. (2005). The role of civil society organisations in policy making process in Rwanda. Journal of Public Administration, 40(4.1), 665-676.

Murekezi, A., \& Loveridge, S. (2009) Paper presentation at the Agricultural and Applied Economics Association Annual Meeting, 26-28 July 2009: Have coffee reforms and coffee supply chains affected farmers' income? The case of coffee growers in Rwanda. Milwaukee, Wisconsin.

Murray, D., Raynolds, L. T., \& Taylor, P. L. (2003). One cup at a time: Poverty alleviation and Fair Trade in Latin America. Retrieved March 4, 2011, from http://www.colostate.edu/depts/sociology/FairTradeResearchGroup/doc/fairtrade.pdf

OCIR Café. (2009). National coffee census 2009. Kigali, Rwanda: Government of Rwanda.

Parrish, B. D., Luzadis, V. A., \& Bentley, W. R. (2005). What Tanzania's coffee farmers can teach the world: A performance based look at the fair trade-free trade debate. Sustainable Development, 13(3), 177-189.

Pinchotti, S., \& Verwimp, P. (2007). Social capital and the Rwandan genocide: A micro-level analysis (HiCN Working Paper no. 30). Retrieved March 4, 2011, from http://www.hicn.org/papers/wp30.pdf 
Pirotte, G., Pleyers, G., \& Poncelet, M. (2006). Fair-trade coffee in Nicaragua and Tanzania: A comparison. Development in Practice, 16(5), 441-451.

Portes, A. (2000). The two meanings of social capital. Sociological Forum, 15(1), 1-12.

Portes, A., \& Landolt, P. (2000). Social capital: Promise and pitfalls of its role in development. Journal of Latin American Studies, 32(2), 529-547.

Potts, J., Meer, J. V. D., Daitchman, J., Carlile, L., Earley, J., Kenney, K., Russillo, A., \& Wunderlich, C. (2010). The state of sustainability initiatives review 2010: Sustainability and transparency. D. Holmes (Ed.). Geneva: IISD, IIED.

Putnam, R. D. (1995). Tuning in, tuning out: The strange disappearance of social capital in America. Political Science and Politics, 28(4), 664-683.

Putnam, R. D. (2001). Bowling alone: The collapse and revival of American community. Toronto, Canada: Simon \& Schuster.

Raynolds, L., Murray, D., \& Heller, A. (2007). Regulating sustainability in the coffee sector: A comparative analysis of third-party environmental and social certification initiatives. Agriculture and Human Values, 24(2), 147-163.

Raynolds, L. T. (2009). Mainstreaming Fair Trade coffee: From partnership to traceability. World Development, 37(6), 1083-1093.

Raynolds, L. T., Murray, D., \& Leigh Taylor, P. (2004). Fair trade coffee: Building producer capacity via global networks. Journal of International Development, 16(8), 1109-1121.

Renard, M.-C. (2005). Quality certification, regulation and power in fair trade. Journal of Rural Studies, 21(4), 419-431.

Robinson, J. P. (1990). The time squeeze. American Demographics, 30-33. 
Ronchi, L. (2002). The impact of fair trade on producers and their organisations: A case study with Coocafe in Costa Rica Retrieved January 12, 2011, from http://www.sussex.ac.uk/Units/PRU/wps/wp11.pdf

Ruben, R. (2008). The impact of Fair Trade. Wageningen, The Netherlands: Wageningen Academic Publishers.

Rubio, M. (1997). Perverse social capital: Some evidence from Colombia. Journal of Economic Issues, 31(3), 805-816.

Sampson, R. J., Raudenbush, S. W., \& Earls, F. (1997). Neighborhoods and violent crime: A multilevel study of collective efficacy. Science, 277(5328), 918-924.

Schneider, P. (2005). Trust in micro-health insurance: An exploratory study in Rwanda. Social Science \& Medicine, 61(7), 1430-1438.

Schuller, T., Baron, S., \& Field, J. (2000). Social capital: A review and critique. In S. Baron, J. Field \& T. Schuller (Eds.), Social capital: Critical perspectives. Oxford, UK: Oxford University Press.

Sick, D. (2008). Coffee, farming families, and Fair Trade in Costa Rica: New markets, same old problems? Latin American Research Review, 43(3), 193-208.

Szreter, S., \& Woolcock, M. (2004). Health by association? Social capital, social theory, and the political economy of public health. International Journal of Epidemiology, 33(4), 650667.

Taylor, P. (2005). In the market but not of it: Fair Trade coffee and Forest Stewardship Council certification as market-based social change. World Development, 33(1), 129-147. 
Uphoff, N., \& Wijayaratna, C. M. (2000). Demonstrated benefits from social capital: The productivity of farmer organizations in Gal Oya, Sri Lanka. World Development, 28(11), 1875-1890.

Utting-Chamorro, K. (2005). Does fair trade make a difference? The case of small coffee producers in Nicaragua. Development in Practice, 15(3\&4), 584-599.

Utting, K. (2009). Assessing the impact of Fair Trade coffee: Towards an integrative framework. Journal of Business Ethics, 86(Supplement 1), 127-149.

Verba, S., Schlozman, K. L., \& Brady, H. E. (1995). Voice and equality: Civic voluntarism in American politics. Boston: Harvard University Press.

Vervisch, T. (2011). The solidarity chain: post-conflict reconstruction and social capital building on three Burundian hillsides. Journal of Eastern African Studies, 5(1), 24-41.

Verwimp, P., \& Nillesen, E. (2007). Recovery of the coffee sector in Rwanda: A farm-level perspective. Paper presented at the War and Poverty, Peace and Prosperity Conference, Berlin. Retreived March 3, 2011, from http://www.epsusa.org/events/07conf/nillesenppt.pdf

Woolcock, M. (1998). Social capital and economic development: Toward a theoretical synthesis and policy framework. Theory and Society, 27(2), 151-208.

Woolcock, M. (2001). Microenterprise and social capital: A framework for theory, research, and policy. The Journal of Socio-Economics, 30(2), 193-198. 